\title{
Keefektifan Model Make A Match Berbantu Media Word Card Terhadap Hasil Belajar Siswa
}

\author{
Irma Anggraeni Aida ${ }^{1 *}$, Choirul Huda ${ }^{2}$, Ikha Listyarini ${ }^{3}$ \\ ${ }^{123}$ Jurusan Pendidikan Guru Sekolah Dasar, Universitas PGRI Semarang
}

\author{
A R T I C L E I N F O \\ Article history: \\ Received 18 May 2019 \\ Received in revised form \\ 30 June 2019 \\ Accepted 15 July 2019 \\ Available online 25 August \\ 2019 \\ Kata Kunci: \\ model pembelajaran make a \\ match, media word card, \\ hasil belajar \\ Keywords: \\ make a match learning \\ model, word card media, \\ learning outcomes
}

\begin{abstract}
A B S T R A K
Penelitian ini bertujuan untuk mengetahui efektif apa tidaknya model pembelajaran make a match berbantu media word card terhadap hasil belajar siswa materi penafsiran data kelas V SD SD N Barusari 01 Semarang. Jenis penelitian ini adalah Quasi Eksperimental Design dengan model Nonequivalent Control Grup. Teknik pengumpulan data menggunakan teknik pengumpulan data tes, observasi dan dokumentasi. Populasi penelitian adalah seluruh siswa kelas V SD N Barusari 01 Semarang. Berdasarkan olah data menggunakan uji-t posttest hasil belajar kelas eksperimen dan kelas kontrol diperoleh $t_{\text {tabel }}$ $=1,67722$ dan $t_{\text {hitung }}=7,9951$ maka kriteria $(\alpha / a, n 1+n 2-2)<t_{\text {hitung, }}$, sehingga diperoleh $1,6772<7,9951$ maka $\mathrm{H}_{0}$ ditolak, dapat disimpulkan bahwa ada perbedaan antara hasil rata-rata nilai posttest lebih meningkat setelah diberi perlakuan dengan menggunakan model pembelajaran make a match berbantu media word card.
\end{abstract}

\section{A B S T R A C T}

This study aimed to determine the effectiveness of whether or not the make a match learning model was a media word card for the learning outcomes of fifth grade students data interpretation material at SD N Barusari 01 Semarang. This type of research is Quasi Experimental Design with the Nonequivalent Control Group model. Data was collect by test, observation and documentation. The population of the study was all fifth grade students of SD N Barusari 01 Semarang. Based on the t-test posttest, learning outcomes of the experimental class and control class by t table $=1.67722$ and thitung $=7.9951$ then the criteria $(\alpha / \mathrm{a}, \mathrm{n} 1+\mathrm{n} 2-2)<$ thitung, obtained $1.6772<7,9951$ then $\mathrm{H} 0$ rejected, it can be concluded that there is a difference between the average yield of the posttest value which increases after being treated by using the learning model make a match assisted by word card media. 


\section{Pendahuluan}

Menurut Undang - Undang Republik Indonesia 20 Tahun 2003 tentang Sistem Pendidikan Nasional "Pendidikan adalah usaha sadar dan terencana untuk mewujudkan suasana belajar dan proses pembelajaran agar peserta didik secara aktif mengembangkan potensi dirinya untuk memiliki kekuatan spiritual keagamaan, pengendalian diri, kepribadian kecerdasan, akhlak mulia, serta ketrampilan yang diperlukan dirinya, masyarakat, bangsa dan Negara". Menurut Munirah (2015) sistem pendidikan di Indonesia dewasa ini tampak ada kesenjangan antara kenginan dan realita. Secara makro dapat dilihat dalam aspek pengelolaan, peran pemerintah dan masyarakat, kurikulum atau materi ajar, pendekatan dan metodologi pembelajaran, sumber daya manusia, lingkungan kampus atau sekolah, dana, dan akreditasi. Kesenjangan dalam sistem pendidikan tersebut disebabkan karena faktor politik, ekonomi, sosial-budaya dan sebagainya yang selalu berubah sesuai dengan perubahan dan perkembangan zaman.

Menurut (2018) Proses pembelajaran yang monoton dengan metode konvensional, semakin memperburuk keadaan ini, proses penyampaian materi yang kurang menarik perhatian siswa akan menurunkan minat siswa untuk mengikuti pembelajaran yang disampaikan oleh guru, hal ini akan berdampak pada hasil belajar siswa itu sendiri. Pembelajaran efektif merupakan suatu pembelajaran yang memungkinkan siswa untuk dapat belajar dengan mudah, menyenangkan dan dapat mencapai tujuan pembelajaran sesuai dengan yang diharapkan. Dengan demikian pembelajaran dikatakan efektif apabila tujuan dari pembelajaran tersebut tercapai. Proses pembelajaran menggunakan media sangat penting bagi siswa karena dapat memberikan solusi terhadap kekurangan dalam metode pembelajaran konvensional yang cenderung menggunakan metode ceramah tanpa mengetahui dan melihat wujud dari obyek pembelajaran yang dijelaskan guru. Menurut Maryani (2015) Media mempunyai Manfaat yang paling penting adalah media dapat mengatasi kekurangan- kekurangan guru dalam menyampaikan pelajaran. Salah satu solusi yang dapat digunakan dalam proses pembelajaran biologi dengan metode penghafalan namun tanpa meninggalkan kesan mudah dan menyenangkan yaitu penggunaan model pembelajaran bermain dengan menggunakan kartu.

Tujuan intruksional dalam pembelajaran pada tingkat pengajaran, dalam bentuknya sebagai terbentuknya kemampuan berpikir (kognitif), watak dan sikap (afektif: emotif dan konatif), dan ketrampilan teknologi (psikomotorik). Taksonomi Bloom (dan pengembangannya) merinci kemampuan tersebut ke dalam kawasan (1) kognitif: pengentahuan, pemahaman, aplikasi, analisis, sintesis, dan evaluasi; (2) afektif (emotif dan konatif) memperhatikan, menerapkan, menghayati nilai, mengorganisasikan dan mempribadikan (internalisasi, menyatugerakan) nilai; dan (3) psikomotorik: persepsi, set, respon terbimbing, respon mekanistis, dan respon kompleks. Dengan tercapainya tujuan intruksional, melalui tujuan pembelajaran akan dicapai, tujuan kulikuler, tujuan institusional, dan tujuan nasional (Soegeng, 2013: 59).

Tujuan tersebut berpengaruh pada hasil belajar siswa dimana hasil belajar akan menentukan seberapa tingkat kemampuan pada siswa. Menurut Sudjana (2010: 22), hasil belajar adalah kemampuan yang dimiliki siswa setelah menerima pengalaman belajar. Menurut Aliputri (2018) Pendidikan dan pengajaran adalah suatu proses yang sadar tujuan. Tujuan dapat diartikan sebagai suatu usaha untuk memberikan rumusan hasil yang di harapkan siswa setelah melaksanakan pengalaman belajar. Pengalaman belajar bisa didapatkan dimana saja, salah satunya di sekolah. Menurut Muslimah (2018) Keberhasilan suatu proses pembelajaran salah satunya ditentukan oleh peran guru dalam mengembangkan metode yang digunakan. Peran guru dalam hal ini adalah bagaimana kreatifitas guru dalam mendesain proses belajar mengajar yang efektif, yaitu proses belajar yang mengembangkan metode dengan penekanan pada partisipasi dan keaktifan siswa di kelas.

Prestasi belajar dipengaruhi oleh dua faktor, internal, dan ekternal. Penyebab utama kesuliatan belajar (learning disabilities) adalah faktor internal, yaitu kemampuan adanya disfungsi neurologis, sedangkan penyebab utama problema belajar (learning problems) adalah faktor eksternal, yaitu antara lain berupa strategi pembelajaran yang keliru, pengelolaan kegiatan belajar yang tidak membangkitkan motivasi belajar anak dan pemberian ulangan penguatan (reinforcement) yang tidak tepat.

Berdasarkan observasi di SD N Barusari 01 Semarang dengan mewawancarai guru kelas V Ibu Franciska Kristianawati bahwa pembelajaran terkait dengan hasil belajar yang rendah pada siswa kelas $\mathrm{V}$ mata pelajaran matematika hal tersebut dilihat dari hasil perolehan nilai harian dan hasil ulangan siswa yang belum memenuhi KKM (Kriteria Ketuntasan Minimal) yang sudah ditentukan. Menurut Sundayana dalam Deni (2017:22) Matematika merupakan salah satu komponen dari serangkaian mata pelajaran yang mempunyai peranan penting dalam pendidikan. Matematika merupakan salah satu bidang studi yang mendukung perkembangan ilmu pengetahuan dan teknologi. 
Dalam pembelajaran matematika siswa sering mengalami banyak kesulitan dalam memahami soal-soal matematika dikarenakan ketidak mampuan siswa dalam memecahkan masalah hitungan. sehingga menyebabkan hasil belajar matematika siswa cenderung rendah.

Dari permasalahan tersebut maka peneliti memilih model pembelajaran Make A Match berbantu Media Word Card. Model Make A Match dipilih peneliti karena dapat mengaktifkan siswa yang pasif menjadi aktif.

Menurut Pista (2016) Make a match merupakan salah satu pembelajaran kooperatif yang dikembangkan oleh Lena Curran dengan teknik mencari pasangan sambil belajar mengenai konsep dalam suasana menyenangkan. Model pembelajaran make a match ini mengutamakan penanaman kemampuan bekerja sama, kemampuan berinteraksi dan kemampuan berpikir melalui permainan mencari pasangan dengan kartu bergambar. Menurut Deschuri (2016) Dengan menggunakan model pembelajaran kooperatif teknik make a match siswa akan lebih bersemangat karena model pembelajaran tersebut terdapat unsur permainannya, selain itu siswa pun dilibatkan langsung dalam pembelajaran. Teknik make a match ini mampu menciptakan kondisi kelas yang interaktif, efektif sebagai sarana untuk melatih keberanian siswa, serta mampu menghilangkan kebosanan siswa ketika pembelajaran berlangsung. Dalam teknik make a match ini siswa akan diberikan kartu klop yang berisi konsep, materi maupun gambar. Mereka akan mencari dan mencocokan kartu gambar dan kartu penjelasan yang mereka pegang. Dalam proses inilah terjadi interaksi antar kelompok dan interaksi antar siswa di dalam kelompok untuk membahas kartukartu yang mereka pegang. Menurut Djumiati (2010) (1) model pembelajaran kooperatif tipe Make A Match bertujuan untuk menumbuhkan sikap saling menghormati, menumbuhkan sikap tanggung jawab, meningkatkan percaya diri dalam menyelesaikan suatu masalah, (2) merupakan model pembelajaran yang menuntut anak didik aktif dalam pembelajaran, keterampilan keterampilan mulai dari tingkat awal maupun tingkat mahir yang dimiliki anak didik akan terlihat dalam pembelajaran ini, (3) lingkungan dalam pembelajaran Make A Match diusahakan demokratis, anak didik diberi kebebasan untuk mengutarakan pendapat. Warsono dan Hariyanto (2012) yang menyatakan bahwa "pembelajaran kooperatif terbukti merupakan pembelajaran yang efektif bagi bermacam karakteristik dan latar belakang sosial siswa karena mampu meningkatkan prestasi akademis siswa. Strategi ini meningkatkan hasil belajar, mendorong untuk saling menghargai dan menjalin persahabatan diantara berbagai kelompok siswa bahkan dengan mereka yang berasal dari ras dan golongan etnis yang berbeda". (hlm. 164). Pembelajaran menggunakan model kooperatif teknik make a match ini dapat mendorong siswa untuk lebih aktif dalam pembelajaran. Model pembelajaran Make A Match merupakan model pembelajaran yang menggunakan kartu- kartu. Pada model ini terdiri dari kartu berisi pertanyaan-pertanyaan dan kartukartu lainnya berisi jawaban dari pertanyaan-pertanyaan berikut. Sedangkan Word Card adalah media kartu, media ini digunakan secara berpasangan, siswa diminta mencari pasangan dari kartu, dengan batas waktu tertentu siswa mencocokan kartu pertanyaan dengan kartu jawaban yang sesusai. Dengan menggunakan model dan media tersebut diharapkan siswa menjadi lebih termotivasi dan aktif dalam melakukan kegiatan pembelajaran di kelas dan pembejaran menjadi lebih menyenangkan. Penelitian ini bertujuan untuk mengetahui: (1) efektif tidaknya hasil belajar siswa setelah diberikan model pembelajaran Make A Match berbantu media Word Card.

\section{Metode}

Pada penelitian ini menggunakan metode kuantitatif. Di dalam penelitian kuantitatif terdapat penelitian eksperimen. Menurut Sugiyono (2013:72) metode eksperimen dapat diartikan sebagai metode penelitian yang digunakan untuk mencari pengaruh perlakuan tertentu terhadap yang lain dalam kondisi yang terkendalikan. Ciri utama penelitian eksperimental adalah adanya pengontrolan variabel dan memberikan perlakuan terhadap kelompok eksperimen (Sugiyono, 2016:196). Penelitian ini menggunakan desain eksperimen tipe Quasi Ecperimental Design dengan tipe Nonequivalent Control Group Design. Dalam desain ini peneliti tidak dapat mengontrol seluruh variabel. Design ini dapat di gambarkan sebagai berikut:

Tabel 1. Desain Ekperimen Nonequivalent Control Group Design

\begin{tabular}{lllll}
\hline Kelompok & & Pretest & Perlakuan & Posttest \\
\hline $\begin{array}{l}\text { Kelas Kontrol } \\
\text { Kelas Eksperimentr }\end{array}$ & $\mathrm{Y}_{2}$ & $\mathrm{X}_{1}$ & $\rightarrow$ & \\
\hline
\end{tabular}


Keterangan:

$\mathrm{Y}_{1} \quad$ : Pretest kelas kontrol

$\mathrm{Y}_{2} \quad$ : Pretest kelas eksperimen

$\mathrm{X}_{1} \quad$ : Pembelajaran menggunkan metode ceramah

$\mathrm{X}_{2} \quad$ : Pembelajaran menggunkan metode make a match

$\mathrm{X}_{1} \mathrm{Y}_{1} \quad$ : Posttest kelas kontrol

$\mathrm{X}_{2} \mathrm{Y}_{2} \quad$ : Posttest kelas kontrol

1. Variabel penelitian

Dalam penelitian dapat diketahui bahwa:

a. Variabel bebas atau independent variable (X) yaitu Sugiyono (2015: 39) mengatakan bahwa Variabel bebas merupakan variabel yang mempengaruhi atau yang menjadi sebab perubahannya atau timbulnyanya variabel dependen (terikat). Variabel bebas pada penelitian ini yaitu model pembelajaran Make A Match berbantu media Word Card.

b. Variabel terikat atau dependent variable (Y) yaitu \Sugiyono (2015 : 39) mengatakan bahwa Variabel terikat merupakan variabel yang dipengaruhi atau yang menjadi akibat, karena adanya variabel bebas. Variabel terikat pada penelitian ini yaitu hasil belajar siswa pada pelajaran matematika.

2. Tempat dan Waktu

a. Tempat Penelitian

Penelitian ini dilaksanakan di kelas V SD Negeri 01 Barusari Semarang.

b. Waktu Penelitiann

Penelitian ini dilaksanakan pada semester genap, tahun ajaran 2019 pada bulan Mei tahun 2019.

3. Teknik Pengumpulan Data

a. Tes

Anastari (1982) dalam Sugiyono (2015:208) menyatakan bahwa tes merupakan pengukuran yang objektif dan standar. Pada penyusunan instrumen tes dilakukan dengan berdasarkan pada kisi-kisi indikator. Tes ini digunakan untuk meningkatkan kemampuan kognitif siswa pada pembelajaran matematika.

b. Observasi

Pada penelitian ini, peneliti menggunakan observasi, yaitu observasi terstruktur yang dirancang secara sistematis, tentang apa yang diamati, kapan dan di mana tempatnya (Sugiono, 2017: 205). Hal tersebut dapat menunjang data yang dibutuhkan peneliti dalam melaksanakan proses penelitian.

c. Dokumentasi

Dokumentasi dilakukan untuk mendapatkan data-data yang diperlukan. Dalam penelitian ini dokumentasi dilakukan untuk memperoleh data nama peserta didik dan nilai dari hasil belajar siswa kelas V SD Negeri Barusari 01.

4. Instrumen Penelitian

a. Intrumen Tes

Instrumen yang digunakan dalam penelitian ini adalah instrument tes yang digunakan untuk mengukur pemahaman konsep berupa soal tes hasil belajar. Penelitian menggunakan instrumen berupa tes yakni soal pilihan ganda. Instrumen tes menggunakan validasi isi dan validasi kontruk.

1) Validitas

a) Validasi Kontruksi ( Construct Validity)

Validitas konstruk dapat digunakan pendapat dari ahli (judgment experts). Dalam hal ini instrument dikontruksi tentang aspek-aspek yang akan diukur dengan berlandaskan teori tertentu, maka selanjutnya dikonsultasikan dengan ahli. Para ahli diminta pendapatnya tentang instrument yang telah disusun (Sugiyono, 2014: 125). Instrumen tes yang akan digunakan untuk penelitian divalidasikan oleh dua dosen perangkat pembelajaran dan dosen materi yaitu Mira Azizah, S.Pd., M.Pd dan Sukamto, S.Pd., M.Pd.

b) Validitas isi

Untuk instrument yang berbentuk tes, pengujian validitas isi dapat dilakukan dengan membandingkan antara isi instrument dengan materi pelajaran yang akan diajarkan. Secara teknis pengujian validitas kontruk dan validitas isi dapat dibantu dengan menggunakan kisi-kisi instrumen. Dalam kisi-kisi terdapat variabel yang diteliti, indikator sebagai tolak ukur dan nomor butir (item) pertanyaan yang telah dijabarkan dari indikator. Dengan kisi-kisi instrumen itu maka pengujian validitas dapat dilakukan dengan mudah dan sistematis (Sugiyono, 2014: 129). 


\section{2) Reliabilitas}

Reliabilitas artinya dapat dipercaya atau dapat diandalkan. Instrumen yang reliabel adalah instrumen yang bila digunakan beberapa kali untuk mengukur obyek yang sama, akan menghasilkan data yang sama (Sugyono, 2014:121).

Dalam penelitian ini menggunakan rumus Borich, yang dikenal dengan Persentage Agreement (PA) yaitu kesepakatan antara penilai yang merupakan suatu persentase kesesuaian nilai antara penilai pertama dengan penilai kedua (Gary D. Borich, 1994:38). Menurut Borich, instrumen yang baik adalah instrumen yang memiliki nilai R lebih besar atau sama dengan 75\% ( $\geq 75 \%)$.

$$
\mathrm{R}=\left(1-\frac{A-B}{A+B}\right) \times 100 \%
$$

Keterangan :

$\mathrm{R}=$ Persentage Agreement

A = Skor yang lebih tinggi dari penilaian

$\mathrm{B}=$ Skor yang lebih rendah dari penilaian

5. Teknik Analisis Data

a. Uji Normalitas

Uji normalitas bertujuan untuk mnguji apakah sampel berasal dari populasi berdistribusi normal atau tidak. Uji normalitas yang digunakan adalah uji liliefors.

b. Uji Homogenitas

Menguji homogenitas digunakan untuk mengetahui apakah sampel berasal dari populasi yang homogeny. Uji homogenitas dalam penelitian ini adalah uji barlett (Sudjana, 2005: 261).

c. Uji-t Pihak Kanan

Uji t dua pihak digunakan untuk menguji hipotesis :

$\mathrm{H}_{0}: \mu 1=\mu 2$

$\mathrm{H}_{1}: \mu 1 \neq \mu 2$

Keterangan :

$\mu 1 \quad$ : rata- rata hasil belajar kelompok eksperimen

$\mu 2 \quad$ : rata- rata hasil belajara kelompok kontrol

Jika $\alpha 1=\alpha 2$ maka statistika yang digunakan adalah :

Keterangan:

$$
t=\frac{\bar{x}_{1}-\bar{x}_{2}}{s \sqrt{\frac{1}{n_{1}}+\frac{1}{n_{2}}}} \quad \text { dengan } \quad S \sqrt{\frac{\left(n_{1}-1\right) s_{1}^{2}+\left(n_{2}-1\right) s_{2}^{2}}{n_{1}+n_{2}-2}}
$$

$\mathrm{t} \quad$ : Perbedaan rata-rata populasi

$\bar{x}_{1} \quad$ : Nilai rata-rata kelompok eksperimen

$\bar{x}_{2} \quad$ : Nilai rata-rata kelompok kontrol

$\mathrm{S} \quad$ : Simpangan baku gabungan

$n_{1} \quad$ : Banyaknya anggota kelompok eksperimen

$n_{2} \quad$ : Banyaknya anggota kelompok kontrol

$s_{1^{2}} \quad$ : Varians kelompok eksperimen

$s_{2^{\mathrm{g}}} \quad$ : Varians kelompok kontrol

Kriteria pengujian adalah: terima $H_{0}$ jika $t_{1-1_{2 a}}<t<t_{1-1_{2 a} \text { dimana }} t_{1-1_{2 a} \text { didapat dari }}$ distribusi t dengan $d k=\left(n_{1}+n_{2}-2\right)$ dan peluang $(1-1 / 2 a)$. Untuk harga - harga $t$ lainnya

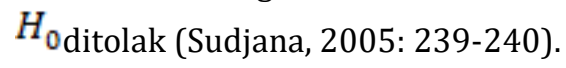




\section{Hasil dan Pembahasan}

A. Analisis Data awal (pretest) Kelas Eksperimen dan Kelas Kontrol

Uji normalitas digunakan untuk mengetahui sampel berasal dari populasi yang berdistribusi normal atau tidak. Uji normalitas yang digunakan adalah uji Liliefors. Kelas kontrol dengan nilai $\mathrm{L}_{0}$ sebesar $0,1199<$ Ltabel sebesar 0,1730 berdistribusi normal. Sedangkan kelas eksperimen dengan nilai $\mathrm{L}_{0}$ sebesar $0,0959<L_{\text {tabel }}$ sebesar 0,1730 berdistribusi normal. Untuk $\mathrm{n}=25$ masing-masing kelas dan taraf $5 \%$, Sehingga kesimpulannya HO diterima. Artinya sampel berasal dari populasi berdistribusi normal.

\section{B. Analisis Data Akhir (Posttest)}

Uji normalitas digunakan untuk mengetahui sampel berasal dari populasi yang berdistribusi normal atau tidak. Uji normalitas yang digunakan adalah uji Liliefors. Kelas kontrol dengan nilai $\mathrm{L}_{0}$ sebesar $0,1000<L_{\text {tabel }}$ sebesar 0,1730 berdistribusi normal. Sedangkan kelas eksperimen dengan nilai $\mathrm{L}_{0}$ sebesar $0,1208<$ Ltabel sebesar 0,1730 berdistribusi normal. Untuk $n=25$ masing-masing kelas dan taraf $5 \%$, Sehingga kesimpulannya H0 diterima. Artinya sampel berasal dari populasi berdistribusi normal.

\section{Uji t dua pihak}

Hasil perhitungan uji t posttest hasil belajar kelas eksperimen dan kelas kontrol pada $\alpha=5 \%$ dengan $\mathrm{dk}=\mathrm{n}_{1}+\mathrm{n}_{2}-2=25+25-2=48$ diperoleh $\mathrm{t}_{\text {tabel }}=1,6772$ dan $\mathrm{t}_{\text {hitung }}=7,9951$ maka kriteria $\mathrm{t}_{\text {tabel }}<$ $\mathrm{t}_{\text {hitung, }}$, sehingga diperoleh $1,6772<2,9528$ maka $\mathrm{H}_{0}$ ditolak dan $\mathrm{H}_{\mathrm{a}}$ diterima. Dapat disimpulkan bahwa ada perbedaan antara hasil rata-rata nilai posttest kelas eksperimen dan kelas kontrol signifikan artinya model pembelajaran make a match berbantu media efektif digunakan pada materi penafsiran data siswa Kelas $\mathrm{V}$ SD Barusari 01 Semarang.

\section{Simpulan dan Saran}

Berdasarkan rumusan masalah, pengajuan hipotesis, analisis data penelitian, dan pembahasan, maka diperoleh kesimpulan bahwa model pembelajran make a match berbantu media word card efektif terhadap hasil belajar Matematika materi Penafsiran Data pada siswa kelas V SD Negeri Barusari 01 Semarang. Hal ini dibuktikan dengan Hasil uji t test dua pihak sebesar 7,9951 dengan taraf signifikan $\alpha=5 \%$ dan $t_{\text {tabel }}=1,6772$. Berdasarkan kriteria pengujian apabila diperoleh nilai $t_{\text {hitung }}>t_{\text {tabel }}$ Ha diterima atau $7,9951>1,6772$, sehingga $\mathrm{H}_{0}$ ditolak dan Ha diterima. Jadi, model pembelajaran make a match berbantu media word card efektif digunkan.

Berdasarkan hasil penelitian yang diperoleh, agar proses pembelajaran dapat memberikan hasil yang maksimal maka peneliti menyampaikan saran sebagai berikut: 1) Bagi guru, dalam pembelajaran dengan menggunkan model make a match berbantu media word card diharapkan dapat menjadi fasilitator, motivasi dan inovator dalam pembelajaran agar dalam pembelajaran siswa tidak bosan. Selain itu guru juga harus kreatif dalam memilih model dan metode sesusai karakteristik siswa dan materi agar hasil belajar mejadi lebih baik. 2) Bagi pembaca, model pembelajaran make a match berbantu media word card ini direkomendasikan oleh penulis agar tetap dapat diterapkan pada pembelajaran karena model pembelajaran ini dapat menumbuhkan semangat siswa dan keaktifan siswa saat belajar. Model pembelajaran make a match berbantu media word card ini dapat coba dan diterapkan pada mata pelajaran dan materi lainnya.

\section{Daftar Rujukan}

Abdurrahman, Mulyono. 2012. Anak Berkesulitas Belajar. Jakarta: Rineka Cipta.

Aliputri, Dhestha Hazilla. 2018. Penerapan Model Pembelajaran Kooperatif Tipe Make A Match Berbantuan Kartu Bergambar Untuk Meningkatkan Hasil Belajar Siswa. Jurnal Bidang Pendidikan Dasar (JBPD), Vol.2 No. 1A Hal. 70-77. Tersedia Pada : http://ejournal.unikama.ac.id/index.php/JBPD/article/view/2351.

Aqib, Zainal. 2013. Model- model, Media, dan Strategi Pembelajaran Kontekstual (Inovatif). Bandung: Yrama Widya.

Arifin, Arifah Novia, Aldi, dan Fiska Indah Reski. 2018. Pengembangan Media Pembelajaran Genetic Vocabulary Cards Untuk Meningkatkan Motivasi dan Hasil Belajar Siswa. Jurnal Sainsmat, Vol. VII, No. 2 Hal. 177-184. Tersedia Pada: http://ojs.unm.ac.id/sainsmat/article/view/8011. 
Arikunto, Suharsimi. 2013. Dasar-Dasar Evaluasi Pendidikan. Jakarta: Bumi Aksara.

Arikunto, Suharsimi. 2015. Prosedur Penelitian Pendekatan Praktik. Jakarta: Rineka Cipta.

Arsyad, Azhar. 2014. Media Pembelajaran. Jakarta: Rajawali Pers.

Deschuri, Cani, Dadang Kurnia, Diah Gusrayani. 2016. Penerapan Model Kooperatif Teknik Make A Match dengan Media Kartu Klop uMeningkatkan Hasil Belajar Siswa pada Materi Kenampakan Alam dan Buatan. Jurnal Pena Ilmiah: Vol. 1, No. 1 Hal. 361-370. Tersedia Pada : http://ejournal.upi.edu/index.php/penailmiah/article/view/3042.

Djumiati. 2010. Model Pembelajaran Make a Match. Jurnal Kependidikan Dasar. Vol 1 No.2

Firmansyah, Deni. 2015. Pengaruh Strategi Pembelajaran dan Minat Belajar terhadap Hasil Belajar Matematika. Universitas Singaper Bangsa.

Huda, miftahul. 2013. Cooperative learning. Yogyakarta: Pustaka Pelajaran.

Karimah, Deni Inayatul. 2017. Keefektifan Model Make A Match Berbantu Media Word Card Terhadap Hasil Belajar Siswa Materi Bangun Ruang Kelas IV SD N 02 Ringin Rembang. Universitas PGRI Semarang.

Maryani, R. 2015. Pengaruh Penerapan Media Biocards Pada Pembelajaran IPA Pokok Bahasan Keanekaragaman Makhluk Hidup Terhadap Hasil Belajar Siswa Kelas VII SMP Negeri 3 Sumber Kabupaten Cirebon. [Skripsi]. Cirebon: Institut Agama Islam Negeri (IAIN) Syekh Nurjati Cirebon.

Mufarokah , Anissatul. 2009. Strategi Belajar Mengajar. Yogyakarta: Teras.

Munirah. 2015. Sistem Pendidikan di Indonesia: antara keinginan dan realita. Auladuna, Vol. 2 No. 2 Hal. 233-245. Tersedia Pada: http://journal.uin-alauddin.ac.id/index.php/auladuna/article/view/879.

Muslimah, Kasmudin Mustapa, Ratman.2018. Penerapan Model Pembelajaran Kooperatif Tipe Make A Match untuk Meningkatkan Hasil Belajar Siswa pada Materi Larutan Elektrolit dan Non Elekrolit di Kelas X Madrasah Aliya DDI Lonja. J. Akademika Kim. Vol. 7 No. 1Hal. 23-27. Tersedia Pada : http://jurnal.untad.ac.id/jurnal/index.php/JAK/article/view/10386.

Novianti. 2017. Penerapan Model Pembelajaran Make A Match Terhadap Kemampuan Komunikasi Matematis Siswa Dengan Mengunakan Geoboard Pada Materi Bangun Datar Di Kelas VII SMP Negeri 2 Bireuen. Universitas Almuslim

Pista, Lusi Ana, Yakobus Ason, Waridah. 2016. Penerapan Model Pembelajaran Kooperatif Tipe Make A Match terhadap Aspek Perkembangan Motorik dan Bahasa pada Anak Usia Dini. Jurnal Pendidikan Dasar Vol. 4 No. 1 Hal. 27-35. Tersedia Pada

Rusman. 2012. Model-model Pembelajaran. Depok: PT Rajagrafindo Persada.

Soegeng, A.Y. 2013. Filsafat Pendidikan. Semarang: Semarang Press.

Sudjana, Nana. 2010. Proses dan Hasil Belajar. Jakarta: Bumi Aksara.

Sudjana, Nana. 2005. Metode Statistik Edisi 6. Bandung: Tarsito

Sugiyono. 2013. Metode Penelitian Kuantitatif Kualitatif dan R\&D. Bandung: Alfabeta.

Sugiyono. 2014.. Bandung: Alfabeta.

Sugiyono 2015. Metode Penelitian Pendidikan (Pendekatan Kuantitatif, Kualitatif, dan R\&D). Bandung: Alfabeta.

Sugiyono. 2016. Metode Penelitian Kuantitatif Kualitatif dan R\&D. Bandung: Alfabeta. 
Sugiyono. 2017. Metode Penelitian Pendidikan. Bandung: Alfabeta.

Sundayana, Rostina. 2015. Media dan Alat Peraga dalam Pembelajaran Matematika. Bandung: Alfabeta.

Syaodih, Nana. 2016. Metode Penelitian Pendidikan. Bandung: PT Remaja Rosdakarya.

Trianto. 2013. Model Pembelajaran Terpadu. Jakarta: Bumi Aksara.

Ulfah, Umi. 2018. Keefektifan Model Pembelajaran Make A Match Terhadap Hasil Belajar Mata Pelajaran Matematika Materi Kelipatan Dan Faktor Bilangan Kelas IV SD Negeri Batursari 02 Mranggen. Universitas PGRI Semarang.

Undang - Undang Republik Indonesia Nomor 20 tahun 2003.

Warsono dan Hariyanto. (2012). Pembelajaran Aktif. Bandung: PT REMAJA ROSDAKARYA. 